\title{
THE EXTENT OF VOLUNTARINESS IN PLEA BARGAINING FOR ECONOMIC AND FINANCIAL CRIMES IN NIGERIA
}

\author{
Ibrahim Danjuma * \\ Gan Ching Chuan**
}

\begin{abstract}
The concept of plea bargaining has globally been recognised and applied in criminal trials so as to enable the accused person to have lighter punishment or to be charge with a lesser offence in a criminal court, while the prosecutor on the other hand will secure conviction. Plea bargaining accommodates the consensual agreement between an accused person and the prosecutor in respect of the case against the accused which is subject to court's approval or acceptance. In Nigeria, the Economic and Financial Crimes Commission (EFCC) is empowered by law to compound offences and to dispose financial and other related offences against the accused persons. Hence, EFCC uses its discretion to apply plea bargaining to some of the cases it prosecutes with the aim of securing conviction and to recover the illegally acquired property from the accused. In the case of Dieprieye Alamiesiegha, after an agreement was reached between him and the prosecutor (EFCC), instead of him pleading guilty as required by law in Nigeria, he explained the reasons why he pleaded guilty. This article examines the cases of plea bargaining in Nigeria and analyses whether or not the admission of guilt by the accused is voluntarily made or is motivated and influenced by some extraneous factors. This article finds that based on the cases analysed, the acceptance of plea bargaining in Nigeria by the accused persons as applied by the EFCC were not made freely and voluntarily as required by the law and best practices in other jurisdictions. This is because the accused persons were forced into it by some certain extraneous factors that were initiated and proffered by the EFCC against provision of the law.
\end{abstract}

Keywords: plea bargaining, voluntariness, EFCC, Nigeria.

Faculty of Law, Bauchi State University Gadau, Nigeria, email: ibrahimdanjuma743047@yahoo.com.

** Associate Professor, Faculty of Law, University of Malaya, Malaysia, email: gancc@um.edu.my. 


\title{
PENGGUNAAN TAWARAN RAYUAN OLEH SURUHANJAYA EKONOMI DAN JENAYAH KEWANGAN DI NIGERIA: KESUKARELAANNYA ATAU SEBALIKNYA
}

\begin{abstract}
ABSTRAK
Konsep "plea bargaining" atau rundingan bagi pengakuan bersalah telah di terima pakai secara global bagi membenarkan seseorang tertuduh bagi mendapatkan hukuman yang lebih ringan atau untuk di dakwa dengan pertuduhan yang lebih ringan di dalam keskes mahkamah. "Plea bargaining" membolehkan pihak tertuduh secara sukarela bekerjasama dengan pihak pendakwa dalam satu kes yang melibatkan tertuduh sendiri, dengan syarat ianya diterima oleh pihak mahkamah. Di Nigeria, Suruhanjaya Ekonomi dan Jenayah Kewangan (EFCC) telah diberikankuasa untuk mengeluarkan kompaun dan menyelesaikan kesalahan-kesalahan yang berkaitan jenayah kewangan. Oleh itu, dalam sesetengah kes, EFCC menggunakan budibicaranya untuk menggunakan "plea bargaining" untuk mendapatkan pengakuan dari pihak tertuduh disamping mendapatkan kembali harta yang telah diambil oleh pihak tertuduh. Walaubagaimanapun, dalam kes Dieprieye Alamiesiegha, sebaliknya telah berlaku. Dalam kes itu, walaupun pihak tertuduh telah berakujanji untuk mengaku salah, apa yang terjadi adalah yang sebaliknya. Pihak tertuduh telah menceritakan kepada Mahkamah apa yang telah dipersetujui antara dia dan pihak pendakwa. Makalah ini melihat kes-kes "plea bargaining" di Nigeria bagi mengenalpasti samada pengakuan yang dibuat didalam kes-kes tersebut diberikan secara rela atau terdapat faktor luaran yang memberi kesan kepada pengakuan tersebut. Kajian ini mendapati penggunaan kaedah "plea bargaining" oleh EFCC bagi mendapatkan pengakuan bersalah dari pihak tertuduh tidak menepati undang-undang dan amalan terbaik dari negara-negara lain kerana ia menyebabkan pengakuan diberi tanpa rela hati.
\end{abstract}

Kata kunci: tawaran rayuan bersalah, kesukarelaan, Suruhan Jaya Ekonomi dan Jenayah Kewangan Nigeria 


\section{INTRODUCTION}

The concept of plea bargaining is an alternative system of resolving criminal trials which is applied in order to reduce case overloads before the courts. ${ }^{1}$ Kevin observed that plea bargaining is just like a contract which is between two parties where the courts will protect and require the parties to fulfill and perform their obligations as agreed between them at the time of concluding the contract. ${ }^{2}$ According to him, the accused person waived some of his rights as enshrined in the Constitution such as the right to remain silent, the right to call witnesses for the defense, the right to jury trial and is allowed to be convicted without the prosecutor proving all the elements of the offence as required by law. ${ }^{3}$ Both parties must commit themselves to the terms of the agreement and non-performance by any of the parties will lead to a breach and the courts will provide a remedy to the aggrieved party. ${ }^{4}$ Suzann and Leonard in their book stated that the practice of plea bargaining can be said to be constitutional or legal only, if the accused is not forced into pleading guilty and he understands the effect or consequences of pleading guilty. ${ }^{5}$

Sandefur ${ }^{6}$ opined that plea bargaining is a contract or agreement with a Government whereby the accused accepts to plead guilty to a minor offence and receives a lighter punishment, rather than facing the trial on a serious offence with the possibility of harsher punishment or sentence. At this juncture, the view of Lynch will be quite interesting to share. ${ }^{7}$ He stated that if plea bargaining is a contract with a State, it should be subjected to the same rules that apply to a contract. In a contract, there is a need to disclose relevant information to the other party about the defect of the subject matter of the contract. That is the prosecutor is said to be obliged to disclose to the accused any disadvantages that he will face by agreeing to the plea bargaining. But in practice such disclosure is not made to the accused. With this, one

\footnotetext{
1 Avimanyu Bahera, "Plea Bargaining in," The Indian Journal of Criminology and Criminalistics 29, no. 1 (2008): 50-54.

Ibid.

Kevin O'Keefe, "Two Wrongs Make a Wrong: A Challenge to Plea Bargaining and Collateral Consequence Statutes Through Their Integration," The Journal of Criminal Law and Criminology 100, no. 1 (2010): 243-76.

4 Ibid.

5 Suzann R Thomas Buckle and Leonard G Buckle, Bargaining for Justice: Case Disposition and Reform in the Criminal Courts (Praeger New York, 1977), 20.

6 Timothy Sandefur, "In Defense of Plea Bargaining," Regulation 26 (2003): 28.

7 Timothy Lynch, “An Eerie Efficiency," Cato Supreme Court Review 1 (2001): 171.
} 
may say that plea bargaining does not satisfy the requirement of a valid contract. One may feel safer to argue that some of the characteristics of plea bargaining are closely related with some features of a contract.

Opponents of the concept argued that the concept provides disparities of punishment, the accused and the prosecutor may have the impression of performing judicial function, it brings about an unfair trial, it is against the proper motive of criminal proceedings in terms of deterrence to others, the guilt of the accused person is determined without evidence and the agreement between the parties is not final but subject to the court's approval. ${ }^{8}$ Some have argued that the concept should not be abolished because it helps in decongesting the prisons, clears backlog cases, saves time and resources where the accused person receives lighter punishment, while the prosecutor will get a judgment in his favour, the looted money and the proceeds are recovered from the offender. ${ }^{9}$

It is trite law that any admission of guilt by the accused person that is influenced by either of the elements of inducement, threat or promise should not be admissible in the court of law. Looking into the circumstances on how plea bargaining agreements were made between prosecutors, the Economic and Financial Crimes Commission (EFCC) and accused persons in Nigeria, for instance, in the case of Dieprieye Alamiesiegha $^{10}$ former Governor of Bayelsa State, Nigeria, while pleading guilty to the charges, the accused said that "his health was deteriorating, his family had been scared and scattered, he has been

Albert Alschuler, "Book Review (reviewing Charles E. Silberman, Criminal Violence, Criminal Justice (1978))," University of Chicago Law Review 46 (1979): 1007; Oguche Samuel, "Development of Plea Bargaining in the Administration of Criminal Justice in Nigeria: A Revolution, Vaccination against Punishment or Mere Expediency?," NIALS Journal of Law and Development, 2010, 49-30. Oladele (2010), cited in G O Adeleke, "Prosecuting Corruption and the Application of Plea Bargaining in Nigeria: A Critique," International Journal of Advanced Legal Studies and Governance 3, no. 1 (2012): 53-70.

9 Ayodele John Alade, "Plea Bargain: The Experience and Its Importance to National Security and Economic Development," in Proceedings of the 2012 National Conference on National Security and Economic Development for Democratic Consolidation, n.d., 426-435; Robert E, Scott and William J, Stuntz, "Plea Bargaining as Contract," Yale Law Journal 101 (1992): 1909-68; T Kehinde Adekunle, "Plea Bargaining and the Nigerian Penal System: Giving Judicial Imprimatur to Corruption," New Ground Research Journal of Legal Studies Research and Essays 1, no. 1 (2013): 10-17; Tan Roger, “A Bargain For Justice," January 4, 2012, http://www.loyarburok.com/2010/12/19/a-bargain-forjustice/.

${ }^{10}$ F.R.N v. Dieprieye Alamiesiegha Charge No. FHC/L/328c/05 (Unreported). 
in detention for too long and he has no option but to plead guilty." It is disturbing to note that plea bargaining agreements between the EFCC and the accused persons in Nigeria were not made with the free will of the accused persons. The accused persons were forced to enter into a plea of guilty due to some extraneous factors. This part intends to analyse the cases where plea agreements were made in order to determine whether they are voluntary or otherwise.

The methodology employed in this article is evaluative and exploratory doctrinal legal research on laws regulating the application of the concept of plea bargaining, charges filed by the EFCC, sealed plea agreement and the cases decided by the courts in Nigeria in respect of the concept. In order to answer the main question as well as to achieve the objectives of this paper, analytical method was used in interpreting the data. It involved systematic exposition, analysis and critical evaluation of charges filed by the EFCC, plea bargaining agreements and the cases decided thereon in order to draw some conclusions about the voluntariness or otherwise of the application of the concept in Nigeria.

\section{PLEA BARGAINING IN DIFFERENT CRIMINAL JURISDICTIONS}

It is of paramount importance to discuss how the concept of plea bargaining was applied in different jurisdictions in order to canvass the scope of the application, the agency regulating the application and the procedure to follow before its application. The scope of the application of plea bargaining in United States extends to all types of offences and most of the criminal cases in the country are resolved through bargaining between the prosecutor and the accused person. ${ }^{11}$ The Supreme Court of the United States has upheld the constitutionality of the concept of plea bargaining in the case of Santo Bello ${ }^{12}$ where the court described plea bargaining as one of the ways of settling criminal trials. Nevertheless, Section 11 of the Federal Rule of Criminal Prosecution of U.S frowns at the involvement of judicial officers in the negotiation between the accused and the prosecutor. This is to maintain the neutrality of the judge and to protect the accused from being forced into the agreement. The system of plea bargaining in the U.S considers

11 Peter J. Messite, "Plea Bargaining in Various Criminal Justice Systems" (Montevideo, Uruguay), accessed September 6, 2015, http://www.law.ufl.edu/ pdf/academics/centers/cgr/11th_conference/Peter_Messitte_Plea_Bargaining. pdf.

12 Santo Bello v.New York, 404 U.S. 257 (1971). 
the victim of the offence to some certain extent to express his view or what he wants in the form of compensation. ${ }^{13}$ Before the judge will finally accept a guilty plea by way of plea bargaining, he has to satisfy that it is voluntarily, the accused understands that by pleading guilty he (accused) has waived his constitutional rights and there is factual basis for the plea. ${ }^{14}$

In India, the concept of plea bargaining was introduced by Section 265 A to L of the Criminal Law (Amendment) Act, No.2 of 2006. The concept applies to offences where the punishment does not exceed 7 years imprisonment and it does not apply to offences against socio-economic condition of the country, offences against a woman or a child below the age of 14 years. ${ }^{15}$ Also, it is the accused person that will initiate the concept of plea bargaining by making an application to court, the court will examine the accused in camera to determine whether it is entered voluntarily and the judgment delivered by the court in respect of plea bargaining is final, and no appeal shall lie against the decision. ${ }^{16}$

In Malaysia, the concept of plea bargaining was architected under Section 172C of Malaysian Criminal Procedure Code. ${ }^{17}$ The concept applies to all types of offences, where the accused will get $50 \%$ reduction from the maximum sentence prescribed by law for the offence he agreed to plead guilty. ${ }^{18}$ Also, it is the accused person that will initiate the concept and the courts will examine the accused to determine whether the application for plea bargaining was voluntarily made. Equally, Nasimah ${ }^{19}$ stated that with the amendment of the Criminal Procedure Code in Malaysia, the concept of plea bargaining strikes out the balance of rights controversy between the accused and the victim of the offence, i.e., the victim of the offence is given an audience in order to express his or her grievances and what kind of compensation he wants from the accused.

It has been observed that countries with the inquisitorial system do not give much emphasis to plea bargaining. This is because of the requirement of compulsory prosecution with a view to finding the truth

\footnotetext{
See Section 21.3 (f) of the Criminal Procedure (3 ${ }^{\text {rd }}$ Edition, 2007)

Messite "Plea Bargaining in Various Criminal Justice Systems", 12.

Bahera, "Plea Bargaining in," 52.

Except as provided under Article 136, 226 and 227 of the India Constitution.

See Criminal Procedure Code (Amendment) Act 2010 (Act A1378).

Roger, "A Bargain For Justice."

Nasimah Hussin, "Punitive Justice in the Malaysian Criminal Law: Balancing the Rights of Offenders with Those of the Victims," Journal of Applied Sciences Research 7, no. 13 (2011): 2399-2404.
} 
i.e. truth can never be compromised and all cases must proceed to trial. ${ }^{20}$ Despite this position, some countries with inquisitorial system like Brazil were able to apply plea bargaining in respect of minor crimes, where the punishment does not exceed two years imprisonment before Special Criminal Courts. ${ }^{21}$ The essence of applying plea bargaining in Brazil was to avoid sentencing the accused to imprisonment in respect of minor offences, due to the fact that the punishments for these minor offences are harsh and ineffective. ${ }^{22}$ The punishment for the minor offences are replaced by fines, reparation to the victim, community work and other remedies, and it can be initiated before filing the charges or during the preliminary stage of the case. Once there is evidence that shows probable cause that a crime has been committed, then prosecutor can negotiate with the accused. ${ }^{23}$

However, plea bargaining in Germany can be in different forms. It can be by way of Diversion Bargaining, where the prosecution may divert or suspend charges conditionally against the accused in exchange for a sum of money or performing charitable work, and it can be by way of Penal Order which should be issued by a judge as requested in case the accused did not object within two weeks. ${ }^{24}$ And the third way is by Judgment Bargaining, where the judge initiates it by offering a lenient sentence to the accused who in turn pleads guilty and it applies to both minor offences and felonies. ${ }^{25}$

Thus, among the reasons for the application of plea bargaining in most of the jurisdictions is to clear backlog cases and to decongest prisons. ${ }^{26}$ But it appears Georgia has a different reason for the application of plea bargaining. This is because the concept is only applied to combat or eradicate corruption. ${ }^{27}$

\section{PLEA BARGAINING IN THE NIGERIAN LEGAL SYSTEM}

There are divergent views regarding the origin of plea bargaining in the

\footnotetext{
$20 \quad$ Ibid., 2409.

$21 \quad$ Ibid., 2411.

22 Ibid., 2412.

23 Hussin, "Punitive Justice in the Malaysian Criminal Law: Balancing the Rights of Offenders with Those of the Victims.".

24 See Section 153a of the German Code of Criminal Procedure

25 Messite, "Plea Bargaining in Various Criminal Justice Systems", 12

26 India, U.SA, Malaysia to mention few

27 Bagirov Anar Ramiz Oglu, "Techical Paper on Plea Bargaining and Issues Related to Its Implemen Tation in Azerbaijan," Support to the Anti Corruption Strategy of Azerbaijan (AZPAC).-2008.-30 P, 2008.
} 
Nigerian legal system. Some are of the view that plea bargaining existed long before the enactment of the Economic and Financial Crimes Commission (EFCC) Act, and Section 76 of the Lagos Administration of Criminal Justice Law largely regulated the application of the concept of plea bargaining in Nigeria. Others argued that the concept was incorporated into the Nigerian legal system after the enactment of EFCC Act in 2002.

Ayodele ${ }^{28}$ argues that a plea bargain is not new to the Nigerian legal system, but it was made known to the public as part of the results of the cases prosecuted by the EFCC. Odinkalu, the Chairman, Governing Council of the National Human Rights Commission, relied on Section 180 (1) of the Criminal Procedure Act (CPA) as a basis for applying the concept ${ }^{29}$ which provides:

When more charges are made against a person and a conviction has been had on one or more of them, the prosecutor may with the consent of the court, withdraw the remaining charge or charges or the court of its own motion, may stay or stop the trial of such charge or charges.

After a thorough examination of the above section, one may conclude that it does not accommodate the full features of plea bargaining. This is because the said section makes it categorically clear that where more charges are made against the accused person in a case and the accused is found guilty on one or more of the charges, the prosecutor can withdraw or the judge su moto may stay the continuation of the trial of remaining charge(s). Under plea bargaining, it is an agreement between the accused and the prosecutor before or after the charge has been filed in court, but before conviction, to jointly agree that the prosecutor will file or change the charge to a lesser one, and in return the accused will plead guilty to the charge(s). Aside from that, plea bargaining also triggers the concept of party autonomy. This means, both the prosecutor and the accused have the control of the outcome of the case. And lastly, plea bargaining in U.S.A, India and Malaysia is informal, because it is not made in the presence of the judge, the judge can only approve or reject it, but the said section empowers the judge to su moto stops proceedings.

Conversely, the former justice of the Nigerian Supreme Court Kayode Eso, stated in an interview which was published on the $18^{\text {th }}$ of November, 2012 that there is no plea bargaining in the Nigerian legal

28 Alade, "Plea Bargain: The Experience and Its Importance to National Security and Economic Development."

29 Chidi Anselm Odinkalu, "Plea Bargaining and the Administration of Justice in Nigeria," Daily Trust Newspaper (Nigeria, April 22, 2012). 
system, and that it was wrongly imported. And according to him, it is even a corruption to import the concept of plea bargaining into the Nigerian legal system.

Former Chief Justice of Nigeria, Justice Dahiru Musdapher at a conference organised by the Nigerian Bar Association in Abuja on $14^{\text {th }}$ November, 2011, stated:

A plea bargain is a novel concept of dubious origin. It has no place in our law substantive or procedural law. It was invented to provide a soft landing for high-profile criminals who loot the treasury entrusted to them. It should never again be mentioned in our jurisprudence. ${ }^{30}$

According to Ephraim, ${ }^{31}$ the prosecution of cases by the EFCC extended the application of the concept of plea bargaining to a greater height and there was never a law to support the application of plea bargaining in the Nigerian legal system. Hence, plea bargaining was never a part of the Nigerian law until recently when EFCC was established and the concept was incorporate into the Act. ${ }^{32}$

Based on the discussion above, it can be strongly argued that plea bargaining was never part of the Nigerian law until recently when the EFCC Act was enacted. This is because the first case of plea bargaining in Nigeria was that of Tafa Balogun in 2005, and then followed by other cases prosecuted by the EFCC.

Moreover, in response to those that argued that section 180(1) of the CPA provides the basis for the application of plea bargaining in Nigeria ${ }^{33}$ and Section 76 of the Lagos Administration of Criminal Justice Law has largely regulated the application of the concept, it is a fact that the CPA applies only to the courts in the Southern part of the country and all the Federal High Courts throughout the country. Therefore, CPA does not apply to all the courts in the country; Criminal Procedure Code applies to the courts in the Northern part of Nigeria. Likewise, the Administration of Criminal Justice Law of Lagos State was enacted in 2007 after the applications of the concept of plea bargaining in the country and it only regulates criminal proceedings in

30 D. Musdapher, [2012]. Paper presented at a 2 day Capacity Building Workshop for Judicial Correspondent at Abuja. title "Legal Practice in Nigeria: Venturing beyond the Usual Borders" Vanguard, Wednesday, June $20^{\text {th }}, 2012$.

31 Ephraim Emeka Ugwuonye, "Plea-Bargain, The Truth Behind The EFCC Moves," 2012, http://elombah.com/index.php/special-repors/10157.

32 Samuel, "Development of Plea Bargaining in the Administration of Criminal Justice in Nigeria: A Revolution, Vaccination against Punishment or Mere Expediency?"

33 Odinkalu, "Plea Bargaining and the Administration of Justice in Nigeria." 


\section{Lagos State.}

It was only recently that the concept of plea bargaining at the federal level was legally introduced under the Administration of Criminal Justice Act (ACJA) 2015. The purpose of the ACJA 2015, is to ensure that the administration of criminal justice in Nigeria promotes efficient management of criminal justice institutions, quick dispensation of justice, protection of the society from crime and safeguarding the rights and the interest of the suspect, accused person and the victim of the offence. ${ }^{34}$ The ACJA 2015 is the combination of the provisions of the two principal legislations, the Criminal Procedure Act and the Criminal Procedure Code into one principal federal Act. The new ACJA of Nigeria applies to only federal courts and courts of the federal capital territory Abuja. ${ }^{35}$

Moreover, section 270 of the ACJA 2015 empowers the prosecutor to receive and consider plea bargaining from the defendant or accused person charged with an offence either directly from that defendant or on his behalf and or to offer a plea bargain to a defendant charged with the offence. ${ }^{36}$ Plea bargaining can be entered into by the prosecution where the available evidence is insufficient to prove the ingredients of the alleged offence(s) beyond reasonable doubt, where the accused person has agreed to return to the victim of the offence or his representative the proceeds of the offence and where the accused person in case of conspiracy, has fully cooperated with the investigation and the prosecution of the crime by providing relevant information for the successful prosecution of other offenders. ${ }^{37}$ The prosecution has to seek the consent of the victim of the offence or his representative before accepting or offering a plea bargain deal to the accused person during or after the testimony of the prosecution's witnesses. ${ }^{38}$

Also, the prosecutor under the ACJA2015, may enter into a plea bargaining agreement if he is of the view that the offer or acceptance of a plea bargain is in the interest of justice, public interest, public policy and the need to preserve the legal process. ${ }^{39}$ But however, the Act is silent as to what connotes interest of justice, public interest and public

\footnotetext{
34 See Section 1(1) of the Administration of Criminal Justice Act of Nigeria, 2015.

35 See Section 1(2) of the Administration of Criminal Justice Act of Nigeria, 2015.

36 See Section 270(1) a \& b of the Administration of Criminal Justice Act of Nigeria, 2015.

37 See Section 270(2) a, b \& c of the Administration of Criminal Justice Act of Nigeria, 2015.

38 See Section 270(2) of the Administration of Criminal Justice Act of Nigeria, 2015.

39 See Section 270(3) of the Administration of Criminal Justice Act of Nigeria, 2015.
} 
policy. It is left to the judgment of prosecutor to decide whether to accept or reject plea bargaining based on the above mentioned reasons.

Under the ACJA 2015, after an agreement has been reached between the accused person and the prosecutor, the agreement has to be reduced into writing containing cautionary words that the accused person has the right to remain silent, he was not forced to make any admission or confession that should be used against him. Terms of the agreement has to signed by both parties before forwarding it to the Attorney General of the Federation. ${ }^{40}$

More so, the prosecutor is duty bound to inform the court that the agreement has been reached between the parties and the presiding judge or magistrate shall inquire from the accused person to confirm the terms of the agreement, to ascertain that accused person admits all the allegations contained in the charge and to determine whether the accused person entered into the agreement voluntarily without any influence or threat before acting upon such terms as contained in the agreement. ${ }^{41}$ And where the accused person is convicted and received a lighter sentence in respect of the same facts of an earlier greater offence charged, he shall not be tried again on the same facts of the greater offence. ${ }^{42}$ Once the court or judge has confirmed from the accused person the correctness of the contents of the agreement and having satisfied that the plea bargaining the agreement was made voluntarily by the accused person, his judgment is final and no appeal shall lie to any court against such judgment except where one of the parties can establish that there was fraud. ${ }^{43}$

The next heading examines the cases of plea bargaining in Nigeria as applied by the EFCC prior to the enactment of ACJA 2015, in order to determine whether the acceptance to make a guilty plea by the accused was voluntarily made or whether such a plea could have been motivated by some factors that may render it involuntarily.

40 See Section 270(7) of the Administration of Criminal Justice Act of Nigeria, 2015.

41 Section 270(9) \& (10) of the Administration of Criminal Justice Act of Nigeria, 2015.

42 Section 270(17) of the Administration of Criminal Justice Act of Nigeria, 2015.

43 Section 270(18) of the Administration of Criminal Justice Act of Nigeria, 2015. 


\section{THE VOLUNTARINESS OF PLEA BARGAING CASES IN NIGERIA PRIOR TO THE ENACTMENT OF ADMINISTRATION OF CRIMINAL JUSTICE ACT 2015}

It is a settled principal in criminal trials that the prosecution has a burden to prove the guilt of the accused person beyond reasonable doubt by establishing all the ingredients of the offence. In doing so, the prosecution has to call witnesses to testify and if necessary tender documents that would establish the guilt of the accused person. The higher number of charges filed in court, the more time and resources are required, i.e. where many charges are filed against the accused person, it will take time to determine the case because the prosecution needs time to call all the material witnesses and tender all relevant documents before the court. The accused also needs time to open the defense of his case. These cannot be done in 2-3 sittings of the court.

Considering the above issues, the prosecutors of EFCC in Nigeria have adopted the practice of overcharging the accused persons by filing too many charges against them with the intent to induce them to accept plea bargaining. Instead of facing 100 charges, which will surely be time and resource consuming, because each charge has to be supported by evidence, the accused person faces fewer charges. This habit of filing 70, 90, and 191 frivolous charges against the accused without proof of evidence serves as a threat to force the accused to accept plea bargaining with the EFCC in Nigeria.

In order to buttress the above issue, it will be of great importance to make references to the plea bargaining cases in Nigeria. Tafa Balogun ${ }^{44}$ was charged to court on 70 count charges by the EFCC at the Federal High Court Abuja, Nigeria in 2005. After bargaining, the charges were reduced to 8 count of charges. The EFCC had abandoned 62 of the charges. He was charged with only $11 \%$ of the initial charges filed and the EFCC waived $89 \%$ of the charges. One may feel that the waived 62 charges were not genuine or the EFCC could not prove them in court. So the EFCC manipulated the charges by increasing them to 70 in order to scare the accused and compel him to accept plea bargaining than facing the whopping 70 charges. To reasonably reduced charges in exchange of pleading guilty, Balogun should have been charged with at least 20 charges, but not on 8 charges considering the total number of charges filed in the court.

Another problematic case that put the voluntariness of plea bargaining into doubt was the case of Dieprieye Alamiesiegha. ${ }^{45}$

\footnotetext{
44 F.R.N v. Tafa Balagun Charge No. FHC/ABJ/CR/14/2005 (Unreported)

45 F.R.N v. Dieprieye Alamiesiegha Charge No. FHC/L/328c/05 (Unreported)
} 
Alamiesiegha was charged at the Federal High Court Lagos, Nigeria on 40 charges by the EFCC. In complying with the terms of the agreement with the EFCC, i.e. to plead guilty to the amended charge, Alamiesiegha informed the court that he decided to plead guilty because of his health, his family members are scathed and scared, and he was detained for a rather long period. ${ }^{46}$ This by implication shows that he pleaded guilty because of the said issues and did not willingly admit to committing the crime. It was a qualified plea. If one considers the position of the law, the judge that heard the case was not supposed to accept that plea of guilty, because it was not voluntarily made. It was motivated or forced by some conditions that are not acceptable in the eyes of the law. $\mathrm{He}$, therefore, did not plead guilty as required by the law of evidence.

The dramatic case where charges were drastically reduced or waived for Lucky Igbinedon, ${ }^{47}$ the former Governor of Edo State, who was arraigned on one hundred and ninety one (191) count charges ${ }^{48}$ also questions the voluntariness of the concept of plea bargaining in Nigeria. After bargaining, the counsel to the EFCC Jacob Rotimi reduced 191 charges to a single count. This is not up to $1 \%$ of the total charges earlier filed by the EFCC. The EFCC suspended or withdrew $99 \%$ charges in the name of bargaining. This is against common sense, how could a person charged with 191 charges containing allegations of stealing billions of Naira be charged with only, a single count. It can be concluded that 190 count charges were manipulated to force the accused to accept the offer of plea bargaining and could not be proven before the court.

The same old tactics were applied to the case of Mrs. Cecilia $\mathrm{Ibru},{ }^{49}$ she was charged on 25 count charges by the EFCC in 2009 at the Federal High Court Lagos and as a sequel to the bargaining, the charges were reduced to only 3 counts. And the last case but not the least, is the case of John Yusuf Yakubu, ${ }^{50}$ who was arraigned on 16 count charges by the EFCC at the Federal High Court Abuja, after bargaining the charges were reduced to 2 counts. In all the cases above, one may say that the EFCC over-charged the accused persons with the intent to force them to accept plea bargaining.

Thus, among the negative implications of refusing to accept a plea bargaining deal on the part of the accused are as follows.

\footnotetext{
46 Ugwuonye, "Plea-Bargain, The Truth Behind The EFCC Moves."

47 F.R.N v. Lucky Igbinedion Charge No. FHC/EN/6C/2008 (Unreported)

48 Ayorinde Oluokun, "EFCC, Courts and Prosecution of Corrupt Politicians," accessed February 27, 2014, http://www.ocnus.net/artman2/publish/Africa_8/ EFCC-Courts-and-Prosecution-of-Corrupt-Politicians.shtml.

49 F.R.N v. Mrs. Cecilia Ibru Charge No. FHC/L/297C/2009 (Unreported).

50 F.R.N v. John Yusuf Yakubu Charge No. FHC/ABJA/CR/54/12 (Unreported).
} 
First, the EFCC may apply to the court to order the accused person to be remanded in EFCC custody pending the completion of investigation, which may go on for two weeks or a month. Thereafter, the accused has to engage the services of a legal practitioner who will file an application for bail. It is all about money, he has to agree with the lawyer regarding his professional fees, the amount to pay for filing of bail application and other related documents. The prosecutor after being served with the bail application, if he is willing to delay the bail application may decide to inform the court that he needs time within which to file counter affidavit to contest the bail application or if the time to file a counter affidavit has elapsed, may decide to file an application for extension of time within which to file a counter affidavit. After hearing the application, the court has to adjourn for ruling on the bail application. At the end of the day, the accused person may spend 2 to 3 months before being released on bail. If the accused person is not lucky, the bail conditions that must be satisfied may be too strict; he has to manage to fulfill them before he can be released on bail.

When the matter proceeds to hearing, the prosecutor may apply for 2 to 3 adjournments before bringing a single witness to the court. Every now and then, the prosecutor may complain that the witness he intends to call was sent for an official assignment to a different State or area. Before you know it, the matter may last for two years without the prosecution closing its case, much less of calling the accused person to open his defense. The accused person may spend a number of years with a case hanging on his neck. Therefore, based on these and many more reasons, it is not surprising if the accused person accepts the plea bargaining deal.

Thus, this problem of involuntariness of plea bargaining as applied by the EFCC in Nigeria prior to the enactment of the Administration of Criminal Justice Act 2015, can be said to be attributed to the lack of necessary safeguards in statutory law and procedural rules regulating the application of the concept of plea bargaining. This is because in India, U.S.A, Malaysia and other countries that apply plea bargaining, there are statutory laws and procedural rules that regulate the practice of plea bargaining.

On the maximum period of detention during investigation, and the right to request for bail once the accused has been charged to court in Indonesia, for instance, the police during an investigation may not hold the suspect in custody for more than 7 days (for offences where the punishment does not exceed 14 years) or 14 days (for offences where the punishment exceed 14 years). In addition, the statutory laws used a mandatory word of "shall" to ensure that the courts examine the 
accused person in camera so as to determine whether the agreement as initiated by the accused was voluntarily made and whether the accused person knows the consequences of accepting the plea deal.

However, the Administration of Criminal Justice Act (ACJA) of Nigeria 2015, ${ }^{51}$ answers to Nigeria's awful need for a new law that will change the criminal justice system so as to echo the true aims of the constitution, the needs to eliminate unacceptable delays in disposing criminal cases and to improve the efficiency of the administration of criminal justice in the country. ${ }^{52}$

\section{CONCLUSION}

It has long been established that any statement made by the accused that is out of fear or prejudice, hope of advantage or inducement by any person in authority should not be admissible as evidence against such an accused person. In other words, the confession or admission of guilt by the accused can only be admissible in court if it is made freely and voluntarily. Thus, considering the attitude of the EFCC in Nigeria by over-charging the accused person and other negative implications of failure to honour a plea bargaining deal, the accused person may have no choice than to accept plea deal.

It is pertinent to note that the practice employed by the EFCC in Nigeria prior to the enactment of ACJA 2015, is to over-charge the accused person in court, to delay the case while holding him in custody with the intent to force him to plead guilty or accept plea bargaining. This clearly shows that plea bargaining in Nigeria as applied by the EFCC is devoid of free will and voluntary confession of the accused person, because such an accused person was forced into it by certain extraneous factors that were initiated and proffered by the EFCC as discussed above. The accused person under this situation has to weigh the time frame, resources, energy, charges filed or to be filed in court and other things on one side and the plea deal which contains a few charges or a single charge with a lesser punishment, thereby accepting the plea deal as the only convenient and easiest choice.

If the intent of the EFCC in Nigeria is to over-charge the accused

$51 \quad$ Administration of Criminal Justice Act (ACJA) 2015 was signed into law on $26^{\text {th }}$ May, 2015 and it is yet to be included into the laws of the Federation.

52 P. Njoku, Comments Off on X-raying plea bargain in new Criminal Justice Administration Act 2015 on $3^{\text {rd }}$ July, 2015 at the Anti-Corruption Commission of the Nigerian Bar Association recently organized a one day seminar, with the theme: "The fight against corruption in Nigeria: The way forward". 
person and adopt delay tactics toward hearing the matter while holding him in custody, then plea bargaining will continue to be involuntarily made since the accused will be forced into it by those factors vitiating the validity of admission of guilt. The court is not supposed to act upon such admission, due to fact that it is not voluntarily made. It is the position of the law that admission of guilt by the accused if voluntarily made is a relevant fact to the case and the court can act upon it.

In conclusion, with the enactment of the ACJA 2015, the issue of forcing or inducing the accused person to accept plea bargaining by the EFCC would be addressed. This is because the new Act empowers the presiding judge or magistrate to ascertain the voluntariness or otherwise of the plea agreement filed before him for consideration. It is important to note here that plea bargaining as contained under the ACJA 2015 has not been tested and applied before any court in Nigeria and all the cases of plea bargaining discussed in this study were treated under the old laws. There is a need for other States in Nigeria to duplicate the ACJA 2015 so as to avoid the EFCC from inducing or forcing the accused person to accept plea bargaining in the States, since they have power to prosecute offenders before State High Courts. On a final note, before the EFCC will file a charge against the accused person, there is the need for the Attorney General of the Federation or State as the case may be, to have a glance at the charges preferred against the accused together with proof of evidence in order to check mate the practice of over-charging the accused person in court with the intent of forcing him to accept plea bargaining and the courts should give zero tolerance to any attempt by the EFCC to delay the proceedings within reasonable time which is one of the constitutional rights the accused enjoys under the Nigerian Constitution. 